\title{
USING ASTER AND GEOCHEMICAL DATA FOR GOLD EXPLORATION, SAMUT AREA, SOUTH EASTERN DESERT, EGYPT
}

\author{
Salem, S. $\mathbf{M}^{1}$, El Sharkawi, $\mathbf{M}^{2}$, El-Alfy, $\mathbf{Z}^{3}$ \& Ahmed, S .E ${ }^{4}$ \\ 1 National Authority for Remote Sensing and Space Sciences \\ 2 Department of Geology, Cairo University \\ 3 Mica-Star Gold Company \\ 4 Department of Geology, Beni Suef University \\ Corresponding author E. mail: salem_moher@hotmail.com Integrated
}

\begin{abstract}
This study investigates the use of ASTER and geochemical data in the exploration of new gold occurrences in altered granodiorite rocks at Samut area in the Eastern Desert of Egypt. The mapping approach developed and applied in this study integrates image (ASTER) and field data sets to produce a map showing the alteration zones within granitoid rocks in the Samut area. Due to the differences in hydrothermally mineral components as well as intensities and influences of these hydrothermal activities on the surrounding rocks, various alteration processes have occurred within the host granodiorite rock. These alteration processes include sericitization, chloritization, silicification and ferrugination, resulted from the chemical interaction between the host rock minerals and mineral bearing ascending solutions. Each of the alteration processes is characterised by significantly altered minerals, in which the sericite and altered plagioclase minerals characterise the sericitization process. The biotite, muscovite, chlorite and hornblende minerals are related to chloritization. The silicification process is manifested by the quartz veins and fractured quartz grains. As well as the iron oxide (magnetite altered to goethite) minerals are characterize the ferrugination process.

The chemical analyses of the unaltered granodiorites country rocks yielded Au content between 0.01 ppm and $1.61 \mathrm{ppm}$, while in the altered granodiorite, Au content is around 0.02 to $14.79 \mathrm{ppm}$. The presence of gold in the unaltered and altered granodiorite even in a low percentage, but in huge tonnages gives an importance and makes the study area worthy of gold exploration and possible exploitation and hence international propagation.

Samut district is made up of intermediate to acidic metavolcanics intruded by a hornblende granodioritic pluton and cut by acidic dykes and quartz veins and veinlets. The associated hydrothermal activity to the plutonic intrusion led to the formation of promising alteration zones for gold in the granodiorite. The clarity and studying of these alterations represent the core and target of this study.
\end{abstract}

Keywords: Samut district; ASTER data; Alteration zones; Gold exploration.

\section{INTRODUCTION}

Samut area is located in the south Eastern Desert of Egypt between latitudes $24^{\circ} 45^{\prime}$ to $24^{\circ} 50^{\prime} \mathrm{N}$ and longitudes $33^{\circ} 50^{\prime}$ to $34^{\circ} 00^{\prime} \mathrm{E}$, covers about $70 \mathrm{~km}^{2}$ (Fig. 1). Gold in the Samut mine occurred in the quartz veins cutting through the granodiorite, and with the extensive mining of these quartz veins since the Pharaonic and Roman times, new sites for gold mining need to be identified either in the alteration zones developed in the granodiorite. This was the motivation of the present study to pinpoint these alterations for exploring gold therein. As well as, Samut area is comfortable and suitable for gold mineralization due to the presence of worthy rocks for gold prospecting.

The gold deposits in the Eastern Desert occur as results of syngenetic and epigenetic processes. In the syngenetic metamorphic model, the gold-bearing fluids may be either circulating sea water (Fripp, 1976) or metamorphic water (Kerrich and Fryer, 1979). The epigenetic hydrothermal Au-bearing quartz veins in 
Salem, et al.

the Egyptian basement are believed to be genetically related to magmatic events (e.g. Pohl, 1988). Pseudohydrothermal processes due to convective cell circulating fluids through fractures are also suggested by Takla et al. (1990). Furthermore, Almond et al. (1984) suggested the derivation of the ore fluids by metamorphism during ophiolite and/or island arc tectonic stages. This is consistent with Boyle (1979) who proposed a greenschist metamorphogenic model for the origin of gold (Helba et al., 2001). Botros (2004) envisaged a combined metamorphic-magmatic origin for these fluids. The gold occurrences and distributions in the Eastern Desert are tectonically controlled by wrench faults and shear zones (Helmy et al., 2004). In this study, the integrated tools of remote sensing and fieldwork were applied to get qualified and promoted results. The use of remote sensing techniques provides detailed mineralogical information and help in mineral mapping and lithological discrimination (Rowan et al., 1977; Goetz et al., 1983; Boardman et al., 1995; Kruse et al., 2003, Zoheir and Lehmann, 2011 and Pour and Hashim, 2012). Zhang et al. (2007) processed ASTER data for extracting the lithology and mineral information that help in detecting alteration zones and characteristic minerals for gold exploration in the south Chocolate Mountains (California). Salem and Soliman (2015) used ASTER data in the identification of alteration zones in the metavolcanics for gold prospecting, east end of Wadi Allaqi, Southeastern Desert, Egypt

Fig. 1: Location map and general view of the Samut area in the Eastern Desert of Egypt.

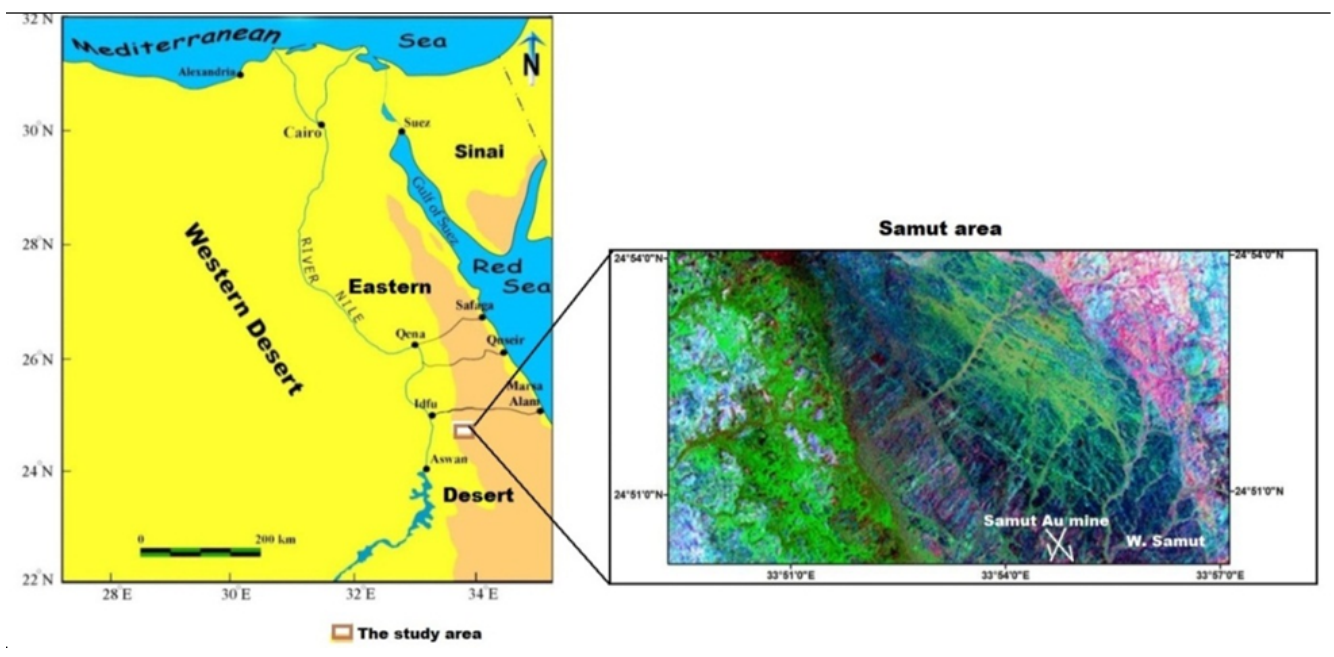

The aim of the present study is to explore gold in the granodiorites and alteration zones at Samut area. A combination of remote sensing field geology and analytical techniques were prepared and used to pinpoint zones of interesting alterations and assessment of the gold contents within the granodiorite rocks and hosted alterations.

\section{GEOLOGICAL SETTING}

The Geology of Samut area was reported by Hume (1937) as hornblende granite closely approximating to a syenite. Azzaz et al. (1981) mentioned that the Samut area comprises diorite, quartz diorite, pink granite cut by granitic dykes and, felsite porphyries and dolerite sheets. Jakubiak (1988) mapped the present area as diorite and quartz diorite with subordinate granodiorite cross cut by quartz veins. The Egyptian Geological Survey and Mining Authority (EGSMA) map (1996) illustrated the geology of Samut area as Precambrian calc-alkaline metamorphosed intermediate-acidic volcanics associated with related pyroclastics of volcanic tuffs and breccias of andesite- dacite composition intruded by hornblende granodiorite plutons. Acidic dykes, granitic sheets and quartz veins and veinlets cut through the granodiorite and the volcanic rocks. These are probably associated with mineral bearing hydrothermal solution led to the formation of mineral bearing alteration zones in the granodiorites. Phanerozoic Nubian sandstones are unconformably overlying the metavolcanics in the western parts of the study area (Fig. 2). Dourgham et al. (2008) described this area as an island arc metasedimentary matrix (meta-andesite, schist and clastic metasedimentary rocks) intruded by late to post-magmatic intrusions of granodiorite rocks which are crosscutting by granodiorite dykes and quartz veins. 
Using aster and geochemical data for gold exploration

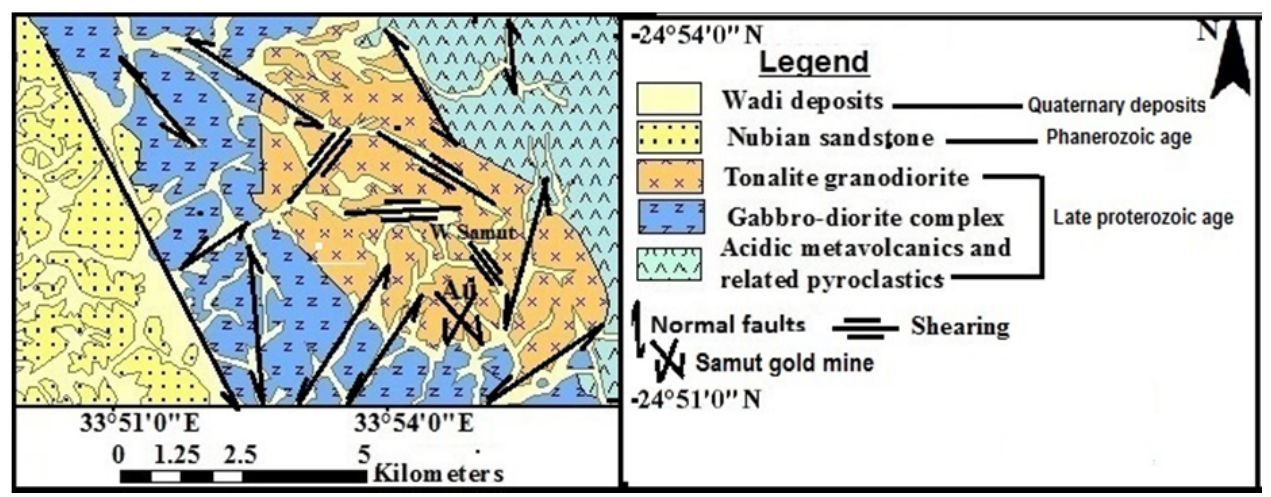

Fig. 2: Geological map of Samut area (modified after EGSMA, 1996).

\section{Methodology}

ASTER data and geologic observations supported by mineralogical and geochemical analyses were integrated and used to finalize and conclude the results of this study.

\section{Remote sensing data}

ASTER data (free level IB ASTER VNIR \& SWIR data Granule ID: ASTL1B 0403150819140808041013)- acquired on March 15, 2008- were digitally pre-processed for georeferencing, atmospheric and radiometric corrections by Arc GIS10 software through conversion of the data to real world coordinates on the area maps to improve the quality of the raw data. They were prepared for image processing by ENVI 4.7 and analysis software ITT Visual information solutions to provide mineral and lithologic discrimination and detect alteration zones and characteristic minerals. Different image processing approaches such as false color composite (FCC) and band ratios have been used to extract the aimed information on the geology and mineralogy of the study area.

FCC bands (7, 5, and 3) in Red, Green, and Blue (RGB) were used to give a general view of the geological and structural features that may control the gold occurrences in the study area. The band ratios transformations in RGB were used for rock and alteration zones identification, (Di Tommaso and Rubinstein, 2007; Aboelkhair et al., 2010 and Salem et al., 2013, 2016). The spectral data for rocks and minerals of the USGS spectral library (http:// www.speclab.cr.usgs.gov) was used to evaluate and correlate the ASTER image spectral signatures considering the identified mineral composition of the different rocks in the study area.

\section{Field Geology and sampling}

Geological fieldwork was undertaken to verify the ASTER interpretation considering the EGSMA (Wadi Ghadir map, 1996) and topographic sheets of Dungash district. Representative samples (GPS controlled) were collected from the granodiorite and altered granodiorite for the mineral and chemical analyses.

\section{Analytical techniques}

The mineralogical investigations were conducted on polished and thin sections of the selected samples using Nikon research microscope in the Geology Department, Cairo University to display the ore and altered minerals associated with the gold.

The available chemical analyses (Atomic Absorption and fire assay analyses) performed by Mica-star company through (OMAC Laboratories Ltd, Ireland) were used and interpreted to chemically characterize the alteration zones and the assessment of the gold content in the granodiorites and in alteration zones. The major and minor elements were analyzed by the atomic absorption method. As well as the fire assay was used to confirm and check the gold and some minor elements.

\section{Results}

The application of ASTER data in the fieldwork, mineral investigation and the chemical analyses lead to recognizing, differentiating and interpreting the targeted altered zones widspread in the granodiorites at Samut area. 
Salem, et al.

\section{ASTER data Interpretations}

FCC

The FCC image bands ( 7,5 , and 3 ) could differentiate between the volcanics in the east (deep brown), plutonics in the middle (pale bluish brown) and Nubian sandstone in the west (yellowish brown color). Also, the FCC displays good drainage pattern and regional geological structural and lineament features e.g.; fault, shearing and folding at Samut area (Fig. 3).

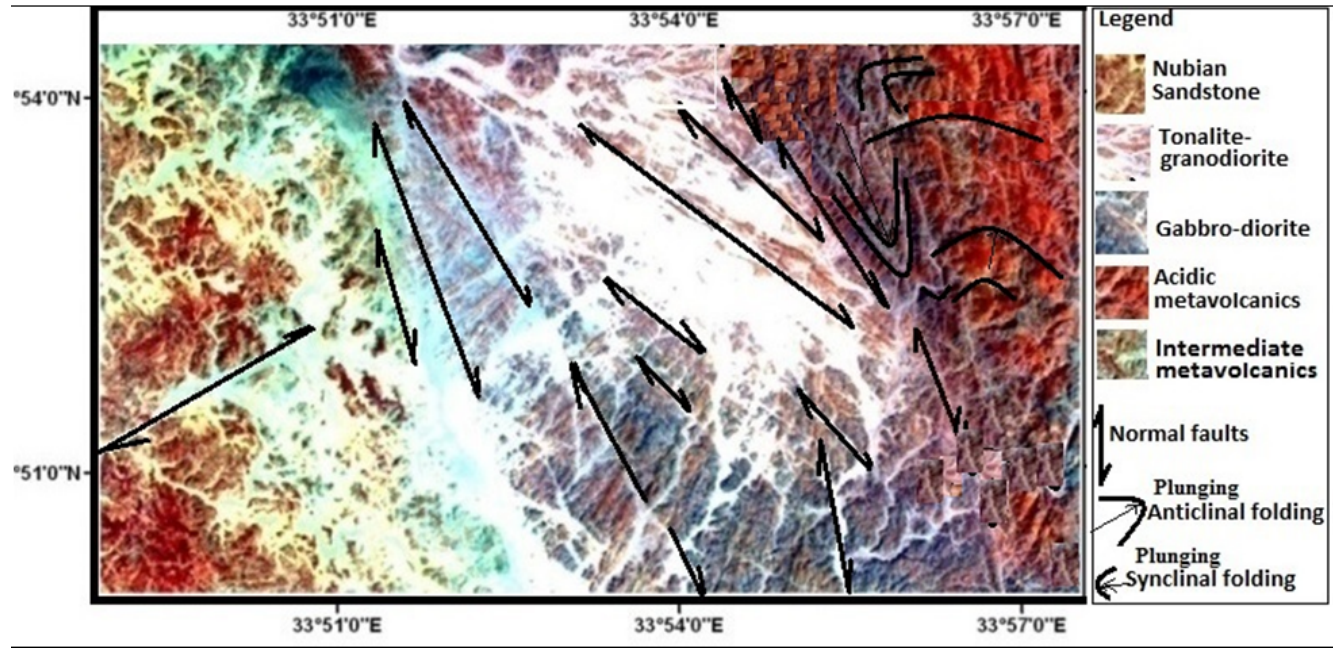

Fig. 3: ASTER

FCC image

bands 7, 5 and 3

in RGB showing

the general

geological and

structural

features at

Samut area.

\section{Band ratios}

ASTER band ratios $(5 / 7,5 / 1,4)$ in RGB helped in differentiating the altered zones in the granodiorite rocks. In this image, the granodiorite appears as blue color, the altered granodiorite in the south (around Samut gold mine) shows mixed blue and brown colors, while the intensively altered granodiorites near and along the contact with the metavolcanics display yellowish greenish red color (Fig. 4). The band ratios (4/5) of ASTER data helped in recognizing detailed discontinuous alteration zones clearly present in the north, east and west of Samut gold mine, these appear as yellowish red and off-whitish creamy colors (Fig. 5). The detected alteration zones are characterized by significantly altered minerals. The following ASTER band ratios were used for identifying these altered minerals;

1: Band math $\{(\mathrm{B} 7+\mathrm{B} 9) / \mathrm{B} 8\}$ reflected the sericite, kaolinite, chlorite and epidote minerals and appeared as yellowish white, yellowish red and blue colors (Fig. 6).

2: Band math $\{(\mathrm{b} 5+\mathrm{b} 7) / \mathrm{b} 6\}$ displayed the clay minerals as whitish creamy and yellowish red colors (Fig. 7).

\section{Field geology}

The fieldwork in Samut area and Samut prospect defined and located the alteration zones that were detected by the remote sensing interpretation in the granodiorites at Samut area.

\section{Samut prospect}

The Samut prospect is developed in an area underlain by acidic metavolcanics and pyroclastics sequence intruded by a granodioritic pluton cut by granitic dykes and quartz veins. The Samut mine is confined to the granodiorite intrusions, situated in the middle and upper reaches of Wadi Samut and its tributaries in the southern periphery of the granitic plutons. At Samut mine area, the most comprehensively investigated zones of the old working for gold mineralization are sets of continuous quartz veins and altered brittle shear zones. These occur around latitudes $24^{\circ} 50^{\prime} 41^{\prime \prime}-24^{\circ} 51^{\prime} 20^{\prime \prime} \mathrm{N}$ and longitudes $33^{\circ} 54^{\prime}$ $38^{\prime \prime}-33^{\circ} 55^{\prime} 00^{\prime \prime} \mathrm{E}$ in the granitic rock at NNE-SSW trend. The first zone (Fig. 8) extends $400 \mathrm{~m}$ in length and $20-30 \mathrm{~m}$ in wide with gold contents range between 0.005 and $1.55 \mathrm{~g} / \mathrm{t}$. 


\section{Using aster and geochemical data for gold exploration}

Fig. 4: ASTER band ratio image $(5 / 7,5 / 1,4)$ in RGB differentiated the alteration zones (yellowish greenish red) from the granodiorite rocks (blue) at Samut area.
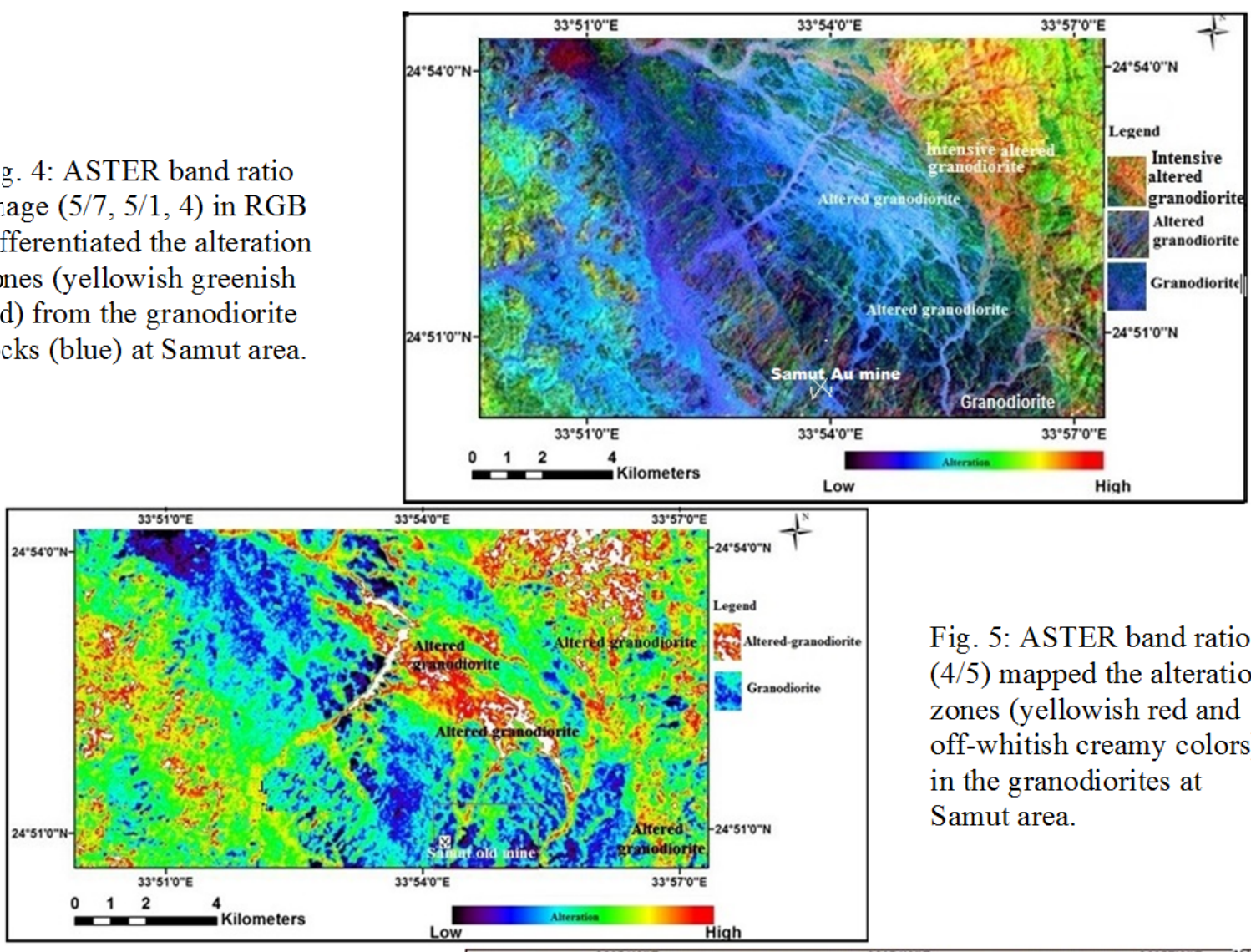

Fig. 5: ASTER band ratio (4/5) mapped the alteration zones (yellowish red and off-whitish creamy colors) in the granodiorites at Samut area.

Fig. 6: Band math $\{(\mathrm{b} 7+\mathrm{b} 9) / \mathrm{b} 8\}$ displayed kaolinite (light yellow), sericite (yellow and pale red), chlorite (blue) and epidote minerals (pale blue color).

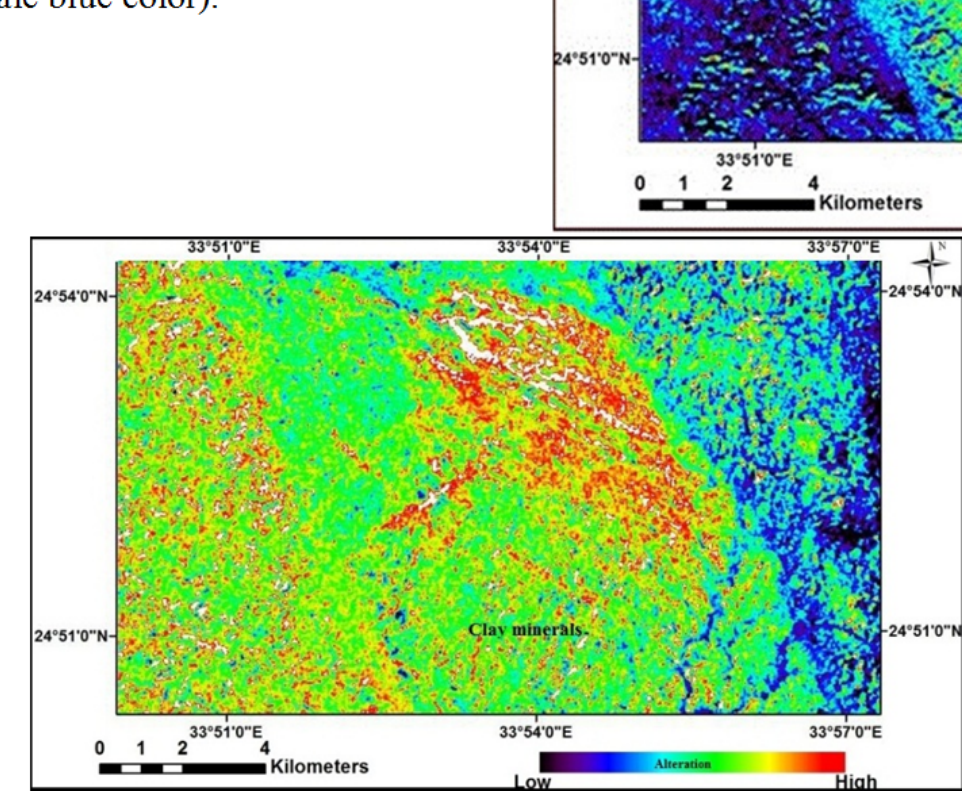

Fig. 7: Band math $(\mathrm{b} 5+\mathrm{b} 7) / \mathrm{b} 6$ revealed the clay minerals as whitish creamy and yellowish red colors. 
Salem, et al.

The second zone (Fig. 9) lies directly at the south of the first one by $100 \mathrm{~m}$ extending in sub longitudinal trend along the main lode at 300 length and 4 to $40 \mathrm{~m}$ in width giving gold contents between 0.002 and $0.6 \mathrm{~g} / \mathrm{t}$ (Azzaz et al 1981). The main vein crops out over a distance of $1100 \mathrm{~m}$ with $3 \mathrm{~m}$ width, stopped down to a depth of $60 \mathrm{~m}$, the old workings are limited to a $500 \mathrm{~m}$ interval in its southern parts. There are numerous quartz veins that have the same trend parallel to the main vein with average thicknesses being $1.0 \mathrm{~m}$ in a sub longitudinal trend $18^{\circ} \mathrm{NNE}$ and dip $65^{\circ}$ eastward. Many quartz veinlets are distributed everywhere around the big quartz vein especially around the main lode in 0.5 to $3 \mathrm{~cm}$ widths and up to few meters lengths.

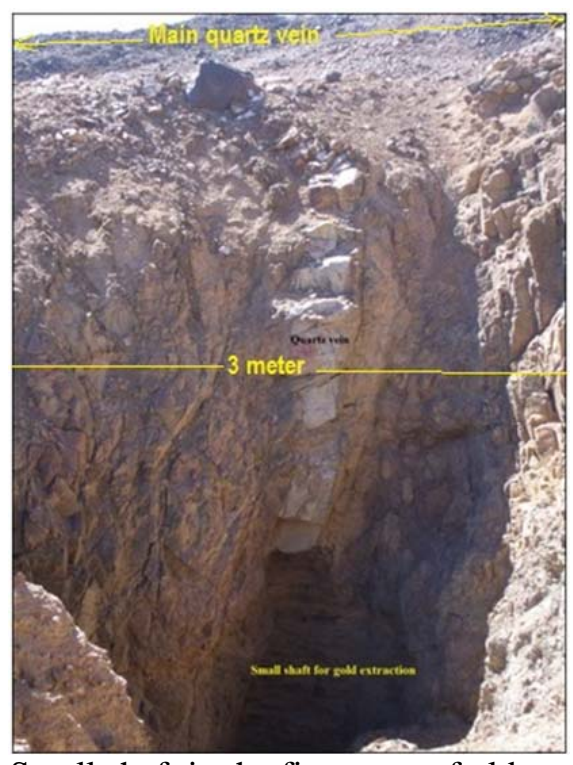

Fig. 8: Small shaft in the first zone of old working to follow the quartz vein for gold exploitation. After Ahmed (2012).

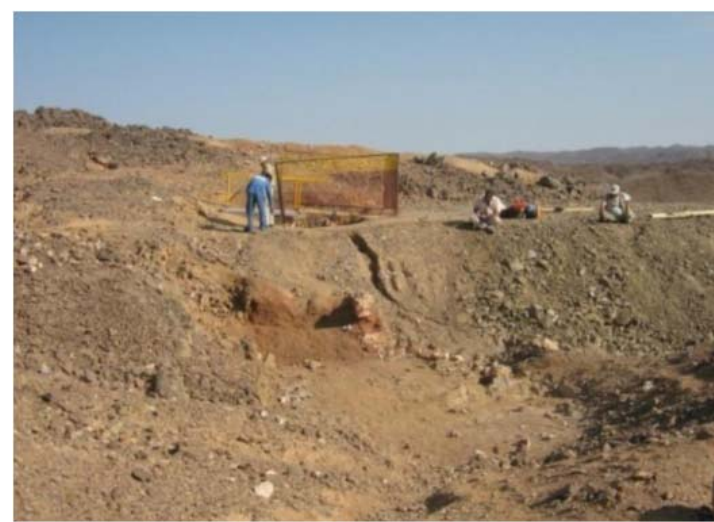

Fig. 9: The second zone of the old working for gold exploitation, south of the main quartz vein. After Ahmed (2012).

\section{Detected alteration zones}

Altered granodiorites around Samut gold mine and intensively altered granodiorites near the contacts with the metavolcanics were differentiated and recognized in the host granodiorite rocks at Samut area. These alterations were developed due to the hydrothermal activity that was associated with the crosscutting granitic dykes, quartz veins and shear planes through the hornblende granodiorites. Neighboring Samut gold mine, the altered zones formed as patches and halos of yellowish brown color enriched in sericite, kaolinite clay minerals as well as pyrite and iron oxides, distributed everywhere -near and around- the crosscutting dykes and fractures (Fig. 10).

Along the contact zones and within the metavolcanics the shearing, fracturing and faulting were severe, hence, granodiorites were intensively altered forming continuous staining and halos of variable sizes and shapes of yellowish brown khaki colors enriched in chlorite, sericite, clay minerals, pyrite and carbonates (Fig. 11). The quartz veins in the altered zones are of white and smoky types, trend $10-20^{\circ}$ and dip eastwards at angles averaging $65^{\circ}$. These veins are extended from $700 \mathrm{~m}$ to $1300 \mathrm{~m}$ with average widths of $2 \mathrm{~m}$, composed of massive and crystalline quartz with ferruginous calcite. Along the shear planes, the early formed quartz veins are brecciated and occasionally traversed by quartz veinlets up to a distance of $1 \mathrm{~m}$ away from the vein contacts in the granodiorite rocks (Fig. 12).

\section{Petrography of granodiorites}

The altered granodiorites are composed of quartz, plagioclase, biotite and hornblende as major minerals, sericite and chlorite are the alteration products. The hornblende is altered completely to uralite and chlorite. The wide distribution of micro fractures and gliding were observed in plagioclase twin lamellae due to deformation and intensive alteration to sericite in the intensively altered granodiorites 


\section{Using aster and geochemical data for gold exploration}

(Figs. 13a and b). The opaque minerals comprises of sulphides and magnetite affected mainly by deformation and alteration, where the magnetite is brecciated, corroded and altered at grain boundaries and along cleavages to goethite, tiny specks of gold occur (Fig. 13c). The sulphides are mostly pyrite clusters or disseminated nano-crystals, some of which could be pyrite or gold grains (Fig. 13d).

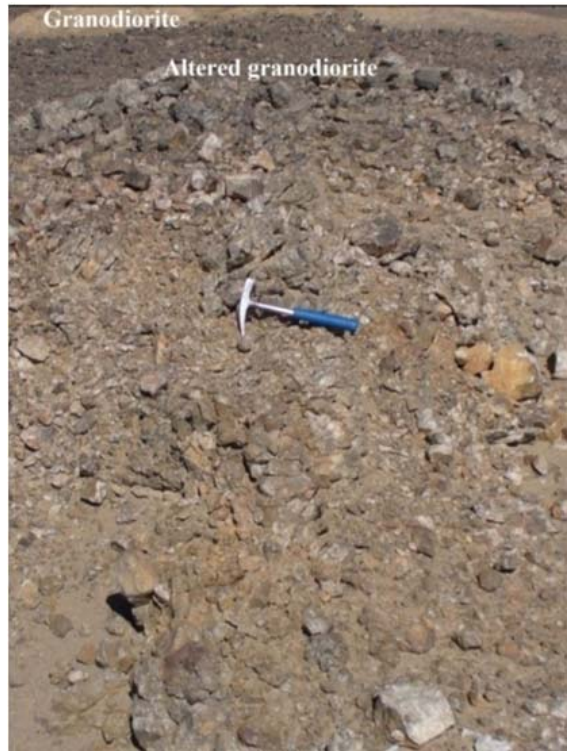

Fig. 10: Field photograph of an altered granodiorite at Samut gold mine area.

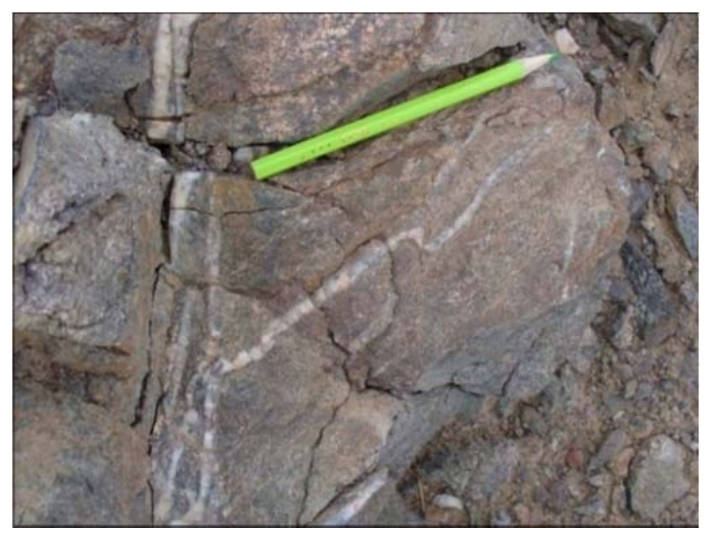

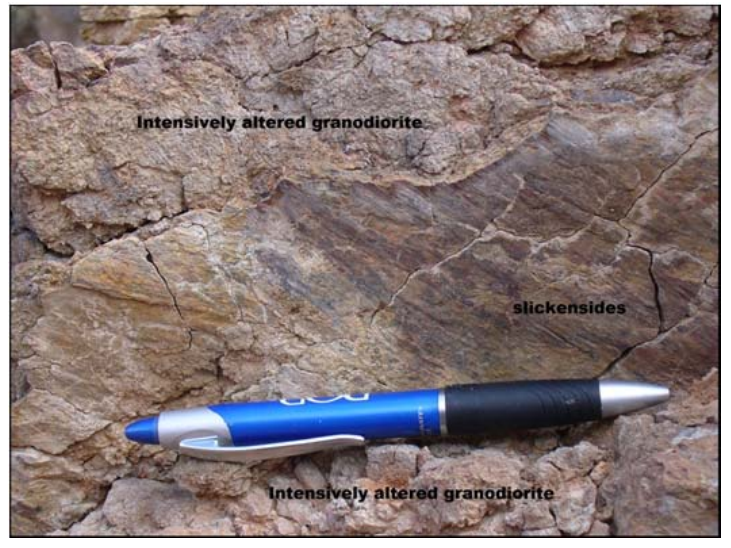

Fig. 11: Field photograph showing altered granodiorite with fault surface marked by slickensides and fractures. NW of Samut mine area (After Ahmed 2012).

Fig.12: Field Photograph of Quartz veins and veinlets cutting granitic rocks with early formed quartz veins brecciated along the newly formed shear plane.

Quartz veins cut the altered rock while the quartz veinlets were observed traversing the older quartz veins. The quartz in the early formed quartz veins is brecciated along the newly formed shear planes (Fig.14a). It occurs as euhedral to subhedral crystals showing wavy extinction due to the strain effect. Secondary quartz is observed in the mineralized quartz veinlets which traverse the older coarse-grained quartz veins in the altered granodiorites (Fig.14b).

\section{Gold content in the granodiorites}

The analyzed samples for major and minor elements of the granodiorites (Tables 1and 2) revealed increasing in $\mathrm{Al}, \mathrm{Ca}, \mathrm{Fe}, \mathrm{K}$ and $\mathrm{Na}$ at the expense of $\mathrm{Mg}, \mathrm{Mn}, \mathrm{P}, \mathrm{S}$ and $\mathrm{Ti}$ suggesting a hornblende granodiorite composition of dominance alkali feldspars (Table 1). The relative increase in $\mathrm{Fe} \%$ may pertain to the leaching from the iron rich hydrothermal activity. In Table 2 the Au contents range around $0.01 \mathrm{ppm}$ and $1.61 \mathrm{ppm}$ found in a random relation with the associated elements of $\mathrm{Ag}, \mathrm{As} \mathrm{Ba}, \mathrm{Ni}, \mathrm{Pb} \mathrm{Co}$ and $\mathrm{Cu}$. 
Salem, et al.

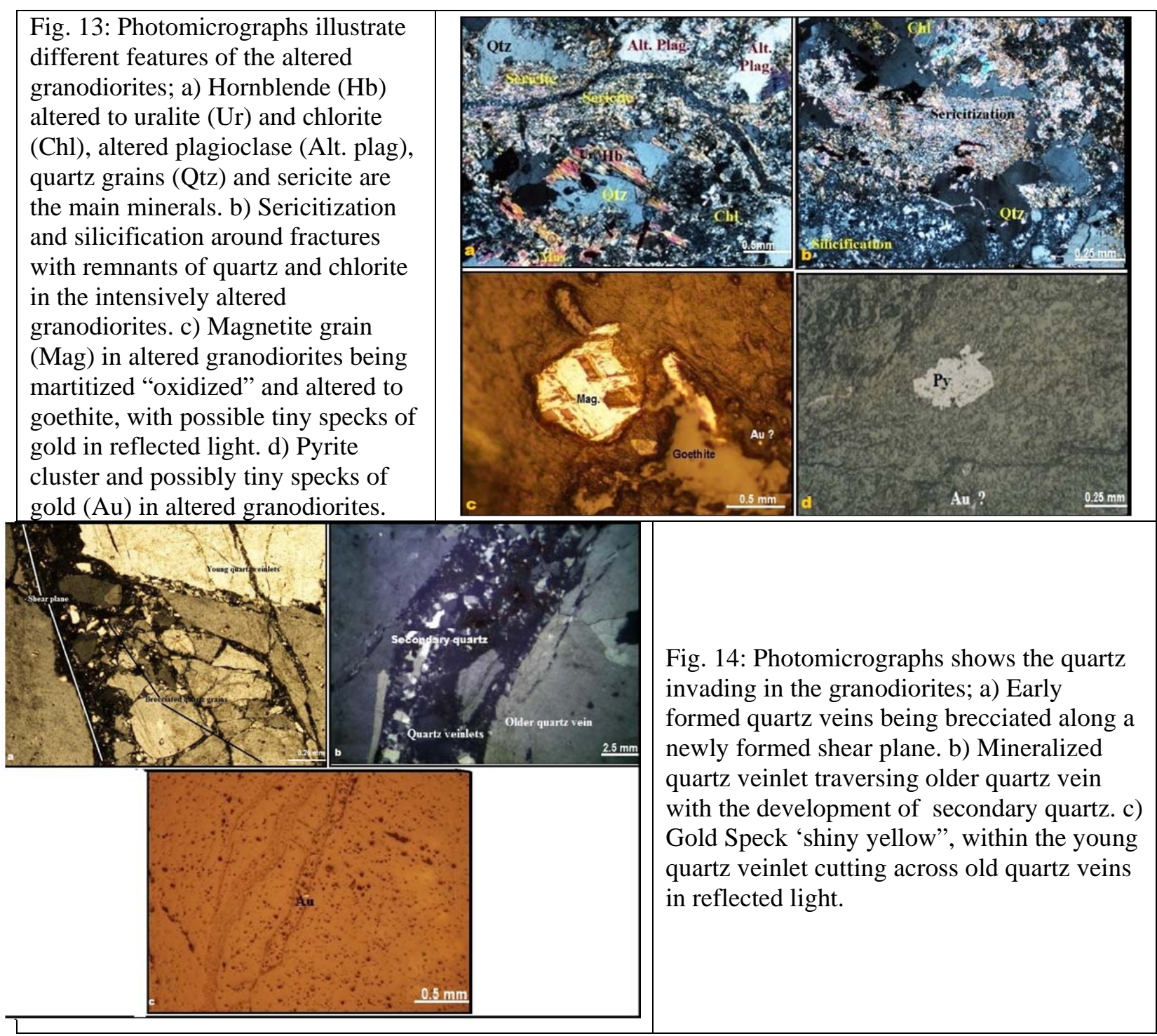

Table 1. Atomic Absorption Analysis of major elements of the granodiorites, Samut area.

\begin{tabular}{|c|c|c|c|c|c|c|c|c|c|c|}
\hline & $\mathrm{Al} \%$ & $\mathrm{C} \%$ & $\mathrm{Fe} \%$ & $\mathrm{~K} \%$ & $\mathrm{Mg} \%$ & $\mathrm{Mn} \%$ & $\mathrm{Na} \%$ & $\mathrm{P} \%$ & $\mathrm{~S} \%$ & $\mathrm{Ti} \%$ \\
\hline 1 & 7.88 & 2.53 & 3.36 & 2.80 & 0.85 & 0.06 & 2.95 & 0.103 & 0.02 & 0.56 \\
\hline 2 & 7.89 & 3.32 & 5.39 & 2.15 & 1.52 & 0.08 & 2.97 & 0.205 & 0.01 & 0.92 \\
\hline 3 & 7.66 & 2.23 & 3.59 & 3.14 & 0.91 & 0.06 & 2.67 & 0.113 & 0.01 & 0.61 \\
\hline 4 & 7.60 & 2.08 & 2.93 & 2.83 & 0.67 & 0.05 & 2.91 & 0.081 & $<.01$ & 0.47 \\
\hline 5 & 7.61 & 1.97 & 2.99 & 2.38 & 0.84 & 0.05 & 2.99 & 0.076 & 0.01 & 0.46 \\
\hline 6 & 7.98 & 3.04 & 3.68 & 3.45 & 1.15 & 0.06 & 2.44 & 0.115 & 0.01 & 0.67 \\
\hline 7 & 8.17 & 3.70 & 4.88 & 2.10 & 1.70 & 0.08 & 2.85 & 0.163 & $<.01$ & 0.88 \\
\hline 8 & 8.10 & 3.11 & 4.85 & 2.21 & 1.49 & 0.08 & 3.18 & 0.171 & 0.01 & 0.86 \\
\hline 9 & 8.06 & 2.26 & 4.64 & 2.22 & 1.39 & 007 & 3.22 & 0.162 & 0.03 & 0.84 \\
\hline 10 & 8.08 & 2.63 & 5.04 & 2.30 & 1.74 & 0.08 & 3.26 & 0.167 & 0.01 & 0.84 \\
\hline 11 & 7.87 & 3.06 & 4.63 & 2.49 & 1.37 & 0.08 & 3.05 & 0.157 & $<.01$ & 0.78 \\
\hline 12 & 7.83 & 2.89 & 4.86 & 2.31 & 1.53 & 0.08 & 3.12 & 0.167 & $<.01$ & 0.82 \\
\hline 13 & 7.90 & 2.70 & 4.92 & 2.39 & 1.46 & 0.08 & 3.39 & 0.169 & $<.01$ & 0.86 \\
\hline 14 & 8.21 & 2.74 & 4.90 & 2.56 & 1.55 & 0.08 & 3.24 & 0.163 & $<.01$ & 0.86 \\
\hline 15 & 8.33 & 5.66 & 4.63 & 2.20 & 1.32 & 0.07 & 2.68 & 0.153 & 0.01 & 0.77 \\
\hline 16 & 6.86 & 1.70 & 2.36 & 4.10 & 0.62 & 0.04 & 2.00 & 0.062 & $<.01$ & 0.37 \\
\hline 17 & 7.96 & 2.95 & 4.98 & 2.49 & 1.52 & 0.08 & 3.27 & 0.162 & $<.01$ & 0.86 \\
\hline 18 & 8.20 & 2.65 & 4.71 & 2.49 & 1.37 & 0.08 & 3.47 & 0.172 & 0.01 & 0.83 \\
\hline 19 & 7.73 & 2.27 & 3.93 & 3.10 & 1.13 & 0.06 & 2.75 & 0.130 & $<.01$ & 0.68 \\
\hline 20 & 8.26 & 3.49 & 4.47 & 2.64 & 1.41 & 0.07 & 3.04 & 0.155 & $<.01$ & 0.75 \\
\hline
\end{tabular}


Using aster and geochemical data for gold exploration

Table 2: Atomic absorption analysis of minor elements of the Granodiorite, Samut area (ppm).

\begin{tabular}{|c|c|c|c|c|c|c|c|c|c|c|c|}
\hline $\begin{array}{c}\text { Sample no } \\
\text { Element ppm }\end{array}$ & $\mathrm{Ag}$ & $\mathrm{Au}$ & $\mathrm{As}$ & $\mathrm{Ba}$ & $\mathrm{Co}$ & $\mathrm{Cu}$ & $\mathrm{Ni}$ & $\mathrm{Nb}$ & $\mathrm{Pb}$ & $\mathrm{Zn}$ & $\mathrm{Zr}$ \\
\hline 1 & 0.5 & 0.01 & $<5$ & 463 & 15 & 103 & 18 & 16 & 13 & 95 & 105 \\
\hline 2 & - & 0.03 & 7 & 396 & 16 & 76 & 38 & 19 & 11 & 76 & 123 \\
\hline 3 & 0.7 & 0.31 & 10 & 456 & 16 & 141 & 29 & 17 & 12 & 91 & 105 \\
\hline 4 & - & 0.47 & 32 & 2941 & 13 & 196 & 36 & 16 & 11 & 68 & 181 \\
\hline 5 & - & 1.46 & 60 & 1114 & 15 & 134 & 35 & 13 & 20 & 93 & 114 \\
\hline 6 & - & 0.60 & 39 & 695 & 16 & 156 & 33 & 17 & 14 & 69 & 145 \\
\hline 7 & - & 1.61 & 19 & 758 & 17 & 212 & 28 & 15 & 22 & 81 & 181 \\
\hline 8 & - & 0.35 & 10 & 450 & 23 & 94 & 69 & 14 & 13 & 76 & 146 \\
\hline 9 & - & 0.40 & 16 & 489 & 22 & 121 & 54 & 13 & 12 & 77 & 139 \\
\hline 10 & - & 0.31 & 789 & 331 & 14 & 101 & 27 & 6 & 16 & 50 & 98 \\
\hline 11 & - & 1.55 & 56 & 502 & 23 & 175 & 48 & 13 & 20 & 103 & 172 \\
\hline 12 & - & 0.24 & 9 & 585 & 21 & 149 & 43 & 14 & 14 & 83 & 178 \\
\hline 13 & - & 0.61 & 33 & 512 & 21 & 70 & 45 & 12 & 9 & 93 & 147 \\
\hline 14 & - & 0.20 & 25 & 524 & 14 & 112 & 32 & 17 & 14 & 63 & 136 \\
\hline 15 & - & 0.38 & 34 & 527 & 16 & 136 & 27 & 14 & 9 & 70 & 198 \\
\hline 16 & - & 0.19 & 7 & 89 & 5 & 22 & 12 & $<5$ & 5 & 19 & 42 \\
\hline 17 & - & 0.04 & 10 & 568 & 23 & 162 & 45 & 15 & 14 & 80 & 220 \\
\hline 18 & - & 0.21 & 8 & 538 & 23 & 162 & 43 & 15 & 17 & 82 & 187 \\
\hline 19 & - & 0.23 & 7 & 724 & 19 & 166 & 33 & 15 & 14 & 82 & 147 \\
\hline 20 & - & 0.56 & 94 & 660 & 16 & 138 & 35 & 17 & 24 & 78 & 161 \\
\hline
\end{tabular}

\section{Gold content in the altered granodiorites zones}

The results from forty analyzed samples of the altered granodiorites for major and minor elements are shown in Tables 3 and 4. In Table 3; Al, Ca, Fe, $\mathrm{K}$ and Na are increasing at the expense of Mg, Mn, P, S and $\mathrm{Ti}$, reflecting sericitization. The depletion of $\mathrm{Na}$ in the alteration zones is mainly accompanied by an increasing in $\mathrm{K}$ depending on the degree of sericitization of the feldspars in the granodiorites.

The fire assay of the gold and Atomic Absorption analysis of the associated elements in the altered samples are shown in Table 4, in which the gold contents range from 0.02 to $14.79 \mathrm{ppm}$. The associated elements show random relationship with the gold in these altered rocks.

\section{DISCUSSION}

The Ancient mining of Samut area was directed to the gold-bearing quartz veins cut in the granodiorite rocks, where the mining operations followed the mineralized quartz veins in the surfaces and depths. That mining activity had entirely exploited and consumed the gold from these quartz veins extensively. In the present study, the altered granodiorite rocks in Samut area were targeted for possible gold mineralization even with the low gold percentages of the alteration zones relative to those in the quartz veins, but with wide dominance and distributions.

The gold deposits of Dungash-Samut district are of orogenic type and show metamorphic, structural and mineralogical features occur along the shear zones crosscutting the granitic intrusions in the area (Groves et al., 1998, 2003). Botros (2004) assumed that the gold deposits at the Dungash-Samut area were not genetically related to the intrusion of the gray or pink granites, instead developed in the late orogenic cycle in the Arabian Nubian Shield. Dourgham et al. (2008) stated that the Dungash-Samut gold deposit is strongly controlled by brittle-ductile shear zones. Zoheir et al (2008) shows that the precipitation of gold was triggered by reactions between the fluids in the shear zones and the country rock at temperatures of $\sim 300^{\circ}$ to $400^{\circ} \mathrm{C}$.

The fractured altered granodiorites acted as venues for the circulating hydrothermal fluids, depositing silica and interacting with the country rocks. Wall-rock alterations of sericitization, chloritization and silicification were developed enriched in significant altered minerals in the granodiorites. The results from image processing of ASTER data complemented by the field geologic work enabled us to discriminate and verify the altered zones. The chemical analyses have proved the presence of gold in the alterations zones and in the unaltered rocks. The gold seems to occur as native gold specks in the altered garnodiorites and within the second phase of silica veining unrelated to the pyritzation process (Figs. 13c, d and14c). In this respect, gold is expected to have been carried in solution with the silica in the second phase of silica veining which should be a target for gold exploration. 
Salem, et al.

Table 3: Atomic Absorption Analysis of major element contents of the analyzed alteration zone, Samut area.

\begin{tabular}{|c|c|c|c|c|c|c|c|c|c|c|}
\hline $\begin{array}{l}\text { Sample no. } \\
\text { Element \% }\end{array}$ & $\mathrm{Al} \%$ & $\mathrm{Ca} \%$ & $\mathrm{Fe} \%$ & $\mathrm{~K} \%$ & Mg\% & $\mathrm{Mn} \%$ & $\mathrm{Na} \%$ & $\mathrm{P} \%$ & $\mathrm{~S} \%$ & $\mathrm{Ti} \%$ \\
\hline 1 & 5.00 & 0.74 & 5.10 & 1.53 & 1.28 & 0.290 & 0.16 & 0.188 & 0.03 & 3.953 \\
\hline 2 & 4.23 & 1.03 & 2.51 & 1.18 & 0.58 & 0.393 & 1.00 & 0.054 & 0.02 & 4.739 \\
\hline 3 & 2.28 & 0.18 & 1.55 & 0.72 & 0.23 & 0.124 & 0.45 & 0.034 & $<.01$ & 1.116 \\
\hline 4 & 5.66 & 0.84 & 4.76 & 2.04 & 1.06 & 0.365 & 1.42 & 0.201 & 0.02 & 6.973 \\
\hline 5 & 1.26 & 0.43 & 1.35 & 0.24 & 0.23 & 1.069 & 0.04 & 0.013 & 0.05 & 0.600 \\
\hline 6 & 5.60 & 0.87 & 3.61 & 1.77 & 0.88 & 0.423 & 1.07 & 0.112 & 0.02 & 5.303 \\
\hline 7 & 7.34 & 1.00 & 5.42 & 3.43 & 0.81 & 0.119 & 0.61 & 0.180 & 0.12 & 5.302 \\
\hline 8 & 3.64 & 0.53 & 6.36 & 1.21 & 0.66 & 0.238 & 0.05 & 0.104 & 0.02 & 1.625 \\
\hline 9 & 6.12 & 1.00 & 5.32 & 2.50 & 0.92 & 0.287 & 0.13 & 0.216 & 0.07 & 6.046 \\
\hline 10 & 5.15 & 1.02 & 5.50 & 2.15 & 1.02 & 0.274 & 0.29 & 0.142 & 0.21 & 4.694 \\
\hline 11 & 2.07 & 0.26 & 2.48 & 0.79 & 0.26 & 0.186 & 0.03 & 0.048 & 0.02 & 1.449 \\
\hline 12 & 7.81 & 4.86 & 3.41 & 2.33 & 0.97 & 0.767 & 1.35 & 0.193 & 0.02 & 8.218 \\
\hline 13 & 5.74 & 5.31 & 4.56 & 2.46 & 1.07 & 0.488 & 0.70 & 0.209 & 0.53 & 8.529 \\
\hline 14 & 6.17 & 0.89 & 5.58 & 3.10 & 0.97 & 0.205 & 0.49 & 0.178 & 0.07 & 6.927 \\
\hline 15 & 6.38 & 1.01 & 6.65 & 2.66 & 0.81 & 0.278 & 0.26 & 0.179 & 0.17 & 4.555 \\
\hline 16 & 7.38 & 2.15 & 6.23 & 2.22 & 1.99 & 1.178 & 0.37 & 0.219 & $<.01$ & 8.005 \\
\hline 17 & 1.50 & 0.33 & 2.07 & 0.44 & 0.23 & 0.169 & 0.03 & 0.040 & 0.04 & 1.410 \\
\hline 18 & 4.73 & 0.71 & 3.93 & 1.37 & 1.38 & 0.429 & 0.79 & 0.113 & 0.02 & 4.292 \\
\hline 19 & 6.93 & 0.71 & 5.83 & 1.12 & 2.21 & 0.555 & 2.16 & 0.164 & $<.01$ & 4.339 \\
\hline 20 & 4.99 & 1.94 & 3.95 & 1.54 & 1.11 & 0.495 & 0.36 & 0.130 & $<.01$ & 4.644 \\
\hline 21 & 4.51 & 0.71 & 3.58 & 1.48 & 0.65 & 0.468 & 0.17 & 0.124 & 0.01 & 5.242 \\
\hline 22 & 4.60 & 1.79 & 4.08 & 1.32 & 1.28 & 0.419 & 0.79 & 0.129 & 0.02 & 3.974 \\
\hline 23 & 4.80 & 0.85 & 4.40 & 1.47 & 1.22 & 0.404 & 0.57 & 0.171 & 0.02 & 5.391 \\
\hline 24 & 1.45 & 0.80 & 1.70 & 0.42 & 0.45 & 0.368 & 0.03 & 0.048 & 0.01 & 1.464 \\
\hline 25 & 7.72 & 1.21 & 6.54 & 2.31 & 1.33 & 0.552 & 0.11 & 0.262 & $<.01$ & 7.285 \\
\hline 26 & 7.87 & 1.88 & 5.44 & 2.19 & 2.19 & 0.892 & 2.27 & 0.165 & 0.01 & 8.304 \\
\hline 27 & 1.76 & 13.38 & 1.63 & 0.41 & 0.53 & 1.057 & 0.20 & 0.069 & 0.02 & 1.642 \\
\hline 28 & 7.54 & 1.80 & 6.28 & 2.20 & 1.64 & 0.841 & 1.86 & 0.274 & 0.02 & 11.769 \\
\hline 29 & 7.77 & 3.10 & 6.68 & 2.09 & 2.08 & 1.011 & 2.40 & 0.211 & 0.01 & 10.790 \\
\hline 30 & 7.80 & 0.89 & 7.50 & 1.86 & 3.01 & 0.701 & 0.08 & 0.122 & 0.08 & 6.474 \\
\hline 31 & 6.60 & 2.08 & 5.22 & 2.19 & 1.76 & 0.538 & 0.18 & 0.136 & 0.31 & 6.648 \\
\hline 32 & 2.06 & 0.98 & 1.61 & 0.41 & 0.48 & 0.224 & 0.70 & 0.036 & $<.01$ & 3.135 \\
\hline 33 & 7.89 & 3.87 & 5.64 & 2.15 & 2.24 & 0.940 & 2.61 & 0.191 & $<.01$ & 8.759 \\
\hline 34 & 7.67 & 2.38 & 6.61 & 1.85 & 2.11 & 0.826 & 1.63 & 0.176 & 0.02 & 9.631 \\
\hline 35 & 4.22 & 2.10 & 3.23 & 1.11 & 1.14 & 0.558 & 1.45 & 0.100 & 0.01 & 5.90 \\
\hline 36 & 5.79 & 2.22 & 5.00 & 1.53 & 1.29 & 0.724 & 1.29 & 0.155 & $<.01$ & 7.904 \\
\hline 37 & 4.93 & 2.15 & 3.64 & 1.21 & 1.13 & 0.562 & 1.58 & 0.123 & 0.30 & 6.164 \\
\hline 38 & 5.39 & 1.24 & 3.57 & 1.94 & 1.29 & 0.614 & 0.22 & 0.092 & 0.04 & 3.015 \\
\hline 39 & 5.13 & 6.17 & 3.96 & 0.99 & 1.31 & 0.840 & 1.54 & 0.101 & 0.01 & 4.693 \\
\hline 40 & 8.76 & 1.75 & 5.50 & 4.00 & 0.59 & 0.278 & 0.06 & 0.301 & $<.01$ & 5.309 \\
\hline
\end{tabular}

\section{CONCLUSION}

The processed ASTER data, field geology and geochemical analyses helped in the detection of the hydrothermally altered zones and the specific altered minerals as new targets for gold exploration in the granodiorite body in the Samut area. The applied tools yielded homogeneous and similar results as the alternations zones were mapped by the ASTER image processing were located and verified in the field,and found in the same image location produced. Also, the petrographic studies identified the altered minerals of sericite, chlorite and clay minerals in rocks sampled in areas where the alterations zones were detected by the remote sensing interpretation. ASTER band ratio (4/5) is the best for detailed mapping of the alteration zones, band math $\{(\mathrm{b} 7+\mathrm{b} 9) / \mathrm{b} 8\}$ is valid for showing carbonates, chlorite and epidote, while band math (b5+b7)/b6 is the suitable for illustrating sericite and clay minerals.

Gold mineralization at Samut area is associated with the sericitization, chloritization and silicification processes developed as fracture fillings and reflected in surfaces exposures. The mineral composition of the alteration zones and country rocks obtained from the ASTER surface data and mineral and chemical analyses indicates that the Samut region is a promising target for gold mineralization because of the existence of extensive and intense alteration zones in the granodiorites. Using the VNIR \& SWIR bands of the ASTER data is important at the beginning of mineral exploration as they give high accuracy data that help in detecting limited and restricted areas of alteration zones as specified targets for mineral exploration saving the time and coast. 


\section{Using aster and geochemical data for gold exploration}

Table 4: Fire assay analysis for gold; and Atomic Absorption analysis of minor elements of the analyzed alteration zone samples, Samut area

\begin{tabular}{|c|c|c|c|c|c|c|c|c|c|c|c|}
\hline $\begin{array}{l}\text { Sample no. } \\
\text { Element ppm }\end{array}$ & $\mathrm{Ag}$ & $\mathrm{Au}$ & As & $\mathrm{Ba}$ & Co & $\mathrm{Cu}$ & $\mathrm{Ni}$ & $\mathrm{Nb}$ & $\mathrm{Pb}$ & $\mathrm{Zn}$ & $\mathrm{Zr}$ \\
\hline 1 & - & 3.11 & 26 & 337 & 12 & 139 & 19 & 7 & 6 & 67 & 30 \\
\hline 2 & - & 0.4 & 21 & 302 & 7 & 48 & 19 & 10 & 24 & 45 & 76 \\
\hline 3 & - & 9.37 & 228 & 159 & 5 & 47 & 11 & $<5$ & 23 & 33 & 40 \\
\hline 4 & - & $0.76 Z$ & 195 & 458 & 15 & 217 & 24 & 14 & 47 & 112 & 82 \\
\hline 5 & - & 0.02 & 9 & 281 & 5 & 34 & 18 & $<5$ & 7 & 34 & 14 \\
\hline 6 & - & 0.40 & 43 & 489 & 13 & 116 & 27 & 12 & 14 & 73 & 76 \\
\hline 7 & - & 0.82 & 40 & 218 & 15 & 74 & 22 & $<5$ & 6 & 87 & 72 \\
\hline 8 & 1.7 & 7.58 & 11 & 1620 & 12 & 72 & 24 & 9 & 7 & 66 & 108 \\
\hline 9 & - & 1.91 & 6 & 1796 & 12 & 78 & 23 & 8 & 6 & 76 & 100 \\
\hline 10 & 2.0 & 12.45 & 54 & 252 & 5 & 177 & 12 & $<5$ & 10 & 45 & 23 \\
\hline 11 & - & 0.48 & 30 & 399 & 15 & 168 & 24 & 14 & 67 & 69 & 146 \\
\hline 12 & - & 0.06 & 35 & 16816 & 1 & 226 & 25 & 12 & 13 & 71 & 120 \\
\hline 13 & - & 0.28 & 14 & 874 & 13 & 75 & 24 & 12 & 13 & 83 & 123 \\
\hline 14 & - & 0.43 & 201 & 338 & 22 & 158 & 40 & 12 & 12 & 92 & 177 \\
\hline 15 & 0.6 & 0.19 & 86 & 109 & 6 & 52 & 10 & $<5$ & 8 & 46 & 26 \\
\hline 16 & 0.6 & 2.27 & 111 & 550 & 11 & 84 & 27 & 8 & 8 & 47 & 96 \\
\hline 17 & - & 0.04 & 233 & 358 & 19 & 139 & 40 & 10 & 8 & 80 & 153 \\
\hline 18 & - & 0.10 & 8 & 563 & 20 & 107 & 42 & 13 & 12 & 117 & 191 \\
\hline 19 & - & 0.19 & 7 & 89 & 5 & 22 & 12 & $<5$ & 5 & 19 & 42 \\
\hline 20 & - & 5.30 & 77 & 233 & 15 & 68 & 51 & 11 & 32 & 85 & 134 \\
\hline 21 & 0.5 & 8.74 & 88 & 290 & 12 & 85 & 26 & 7 & 7 & 65 & 100 \\
\hline 22 & - & 4.79 & 39 & 291 & 12 & 92 & 28 & 8 & 8 & 57 & 113 \\
\hline 23 & - & 0.51 & 112 & 583 & 19 & 228 & 30 & 16 & 10 & 77 & 190 \\
\hline 24 & - & 0.27 & 71 & 95 & 4 & 110 & 12 & $<5$ & 18 & 19 & 45 \\
\hline 25 & - & 0.14 & 8 & 557 & 22 & 144 & 42 & 15 & 11 & 92 & 167 \\
\hline 26 & - & 0.01 & $<5$ & 121 & 5 & 11 & 14 & 5 & $<3$ & 24 & 48 \\
\hline 27 & - & 0.02 & 8 & 518 & 21 & 103 & 55 & 14 & 11 & 79 & 187 \\
\hline 28 & - & 0.02 & 53 & 419 & 23 & 90 & 54 & 14 & 10 & 83 & 165 \\
\hline 29 & - & 0.20 & 724 & 370 & 18 & 92 & 39 & 11 & 10 & 66 & 136 \\
\hline 30 & - & 0.02 & 21 & 302 & 12 & 60 & 26 & 10 & 16 & 51 & 102 \\
\hline 31 & - & 0.16 & 122 & 33 & 2 & 13 & 7 & $<5$ & $<3$ & 10 & 6 \\
\hline 32 & - & 0.01 & 14 & 145 & 6 & 43 & 15 & $<5$ & 5 & 25 & 46 \\
\hline 33 & - & $<.01$ & 53 & 343 & 17 & 98 & 37 & 8 & 9 & 56 & 107 \\
\hline 34 & - & 0.02 & 16 & 45 & 7 & 31 & 23 & 6 & 12 & 47 & 26 \\
\hline 35 & - & 0.02 & 117 & 197 & 13 & 84 & 22 & 8 & 8 & 55 & 52 \\
\hline 36 & 0.5 & 0.73 & 15349 & 674 & 15 & 266 & 18 & 8 & 10 & 52 & 195 \\
\hline 37 & 0.6 & 2.16 & 9549 & 131 & 6 & 30 & 9 & $<5$ & 11 & 19 & 53 \\
\hline 38 & - & 0.12 & 351 & 96 & 2 & 8 & 6 & $<5$ & 5 & 19 & 5 \\
\hline 39 & - & 0.12 & 135 & 213 & 14 & 88 & 20 & $<5$ & 6 & 54 & 46 \\
\hline 40 & 0.6 & 14.79 & 130 & 9 & 1 & 5 & 4 & $<5$ & 47 & 40 & 2 \\
\hline
\end{tabular}

- Not detected

\section{ACKNOWLEDGEMENTS}

Great thanks are due to National Authority for Remote Sensing and Space Sciences for ASTER data supplying and due to Matz Holdings Ltd Company for gold exploration at Dungash Samut area) for providing this study with the available geochemical analyses. Thanks also for the Geology Department, at Cairo University for allowing the use of the Research Nikon microscope for petrographic analysis.

\section{REFERENCES}

Aboelkhair H, Yoshiki N, Yasushi W, Isao S (2010): Processing and interpretation of ASTER TIR data for mapping of rare-metal-enriched albite granitoids in the Central Eastern Desert of Egypt. J. Afr. Earth Sci. 58(1): 141-151.

Ahmed, SE (2012): Application of remote sensing techniques on gold mineralization and exploration at dungash and samut mines, South eastern desert, Egypt. M. Sc, Cairo Univ., http://erepository.cu.edu.eg/index.php/cutheses/article/view/3022/2979 
Salem, et al.

Almond, D. C., Ahmed, F., and Shaddad, M. Z., (1984): Setting of gold mineralization in the northern Red Sea hills of Sudan: Economic Geology, 79, 389-392.

Azzaz, S. A., Khalid, A. M., Abass, Y. A., El Gamal, E. A., and Zaki, M. E., (1981): Results of prospecting- evaluation work carried out at Samut gold ore deposit. EGSMA. Internal report (64 /1981).

Boardman JW, Kruse FA, Green RO (1995): Mapping target signatures via partial unmixing of AVIRIS data In: Green RO (Ed) Summaries of the Fifth JPL Airborne Earth Science Workshop JPL Publ 95-1 Pasadena CA 1: 23-26.

Botros NS (2004): A new classification of the gold deposits in Egypt. Ore Geol. Rev., 25: 1-37.

Boyle, R. W., (1979): The geochemistry of gold and its deposits. Geol. Surv. Can. Bull.,280,383p.

Di Tommaso I, Rubinstein N (2007) Hydrothermal alteration mapping using ASTER data in the infernally porphyry deposit, Argentina. Ore Geol. Rev., 32: 275-290.

Dourgham IA, Fawzy KM and Frimmel HE (2008) Petrology, mineralogy, geochemistry and fluid inclusions of the Dungash gold deposit, South Eastern Desert, Egypt, Egyptian Mineralogist. Accepted.

EGSMA (1996) Geologic map of Wadi Ghadir Quadrangle, Egypt, scale 1:100 000. Egyptian Geological Survey and Mining Authority Cairo Egypt.

Fripp, R.E.P., (1976) Strata bound gold deposits in Archean banded iron formation, Rhodesia. Econ. Geol. $71,58-75$.

Goetz AFH, Rock BN, Rowan LC (1983) Remote sensing for exploration, an overview. Econ Geo 78:573-590, Full Text via bCross Ref View Record in Scopus Cited By in Scopus (43).

Groves DI, Goldfarb RJ, Robert F, Hart CJR (2003) Gold deposits in metamorphic belts: overview of current understanding, outstanding problems, future research, and exploration significance. Economic Geology 98: 1-29.

Groves, D.I., Goldfarb, R.J., Gebre-Mariam, M., Hagemann, S.G., and Robert, F., (1998): Orogenic gold deposits: A proposed classification in the evolution of the Um Egat and Dungash orogenic gold deposits, Egyptian Eastern Desert context of their crustal deformation and relationship to other gold deposit types: Ore Geol. Rev., 13, 7-28.

Helba HA, Khalil KI and Abdou NM (2001): Alteration patterns related to hydrothermal gold mineralization in meta-andesites at Dungash area, Eastern Desert, Egypt. Resource Geol., 51: 19-30.

Helmy H. M., Kaindl R, Fritz H, Loizenbauer J (2004): The Sukari gold mine, Eastern Desert-Egypt: structural setting, mineralogy and fluid inclusion study. Mineralium Deposita 39, 495-511.

Hume, W. F., (1937): Geology of Egypt, Vol. II The fundamental Pre-Cambrian Rocks of Egypt and the Sudan, their Distribution, Age and Character, Part Ill. The Minerals of Economic Value. Government Press.

Jakubiak, Z. (1988): An assessment of gold potential of the Fatiri, Umm Rus and Barramiya area in the Eastern Desert, Egypt. Egypt. Geol. Surv., Internal Report (56/91).

Kerrich, R., Fryer, B. J., (1979): Archean precious metal hydrothermal systems, Dome mine, Abitibi greenstone belt. II. REE and oxygen isotope relations. Can. J. Earth Sci.16, 440-458.

Kruse F.A., Boardman J.W. and Huntington J. F. (2003): Evaluation and Validation of EO-1Hyperion for mineral mapping, IEEE Trans. Geosci. Rem. Sens., 41(6), 1388- 1400 [doi: 10.1109/ TGRS.2003.812908].

Pohl W. (1988): Precambrian metallogeny of NE-Africa In: El Gaby S, Greiling RO (Eds.), The PanAfrican Belt of NE Africa and adjacent areas. Wiesbaden, Earth Evolution Science, p. 319-341.

Pour, A. B., Hashim, M. (2012): The application of ASTER remote sensing data to porphyry copper and epithermal gold deposits Ore Geology Reviews, 44, 1-9.

Rowan L. C., Goetz AFH and Ashley R. P. (1977): Discrimination of hydrothermally altered and unaltered rocks in visible and near infra-red multispectral images. Geophysics 42(3), 522-535.

Salem S. M., Soliman N. M., Ramadan T. M. and Greiling R. O. (2013): Exploration of new gold occurrences in the alteration zones at the Barramiya District, Central Eastern Desert of Egypt using ASTER data and geological studies, Arab J Geosci, 7, (2014), 1717-1731.

Salem M. Salem_and Soliman, N. M. (2015): Exploration of gold at the east end of Wadi Allaqi, South Eastern Desert, Egypt, using remote sensing techniques, Arab J Geosci, (2015), 8, 11, 9271-9282. 


\section{Using aster and geochemical data for gold exploration}

Salem, S. M., El Sharkawi, M., El-Alfy, Z., Soliman, N. M., Ahmed, S. E. (2016): Exploration of gold occurrences in alteration zones at Dungash district, Southeastern Desert of Egypt using ASTER data and geochemical analyses. J. Afric. Earth Sci., 117, 389-400.

Takla, M. A., El-dougdoug, A. A., Rasmy, A. H., Gad, M. A., El- Tabbal, H. K., (1990): Origin of Um Eleiga gold mineralization, South Eastern Desert, Egypt. Egypt. Mineral. 2, 3-20.

Zhang X, Pazner M, Duke N (2007): Lithologic and mineral information extraction for gold exploration using ASTER data in the south Chocolate Mountains (California). Photogrammetry \& Remote Sensing, 62, 271-282.

Zoheir B, EL-Shazly A. A. K., Helba H, Khalil K. I. and Bodnar R. J. (2008): Origin and Evolution of the Um Egat and Dungash Orogenic Gold Deposits, Egyptian Eastern Desert: Evidence from Fluid Inclusions in Quartz. Economic Geology, 103, 405-424

Zoheir B and Lehmann B (2011): Listwaenite-lode association at the Barramiya gold mine, Eastern Desert, Egypt. Ore Geol. Rev. 39: 101-115.

USGS spectral library of rock forming minerals, http:// www.speclab.cr.usgs.gov. 
Salem, et al.

\section{استخدام بيانات الأستر والجيوكيمياء لاستكثاف الذهب في منطقة سموت جنوب الصحراء الثرقية سالم محمد سالم و محمد عبد الحميد الثرقاوي و زينهم سيد الالفي وسارة عزت احمد الخلاصة}

يتكون نطاق سموت من صخور بركانية منوسطة وحامضية منداخلة بصخور الجرانوديوريت الجوفية ومقطوعة بقواطع بركانية حامضية وعروق من الكوارتز ـ أدت المحاليل الحارمائية المصاحبة لهذا التداخل الجوفي إلى تكوين نطاقات تغير واعدة بالذهب في صخور الجرانوديوريت .

توضيح ودراسة هذه النطاقات المتغيرة يمنل الهدف من هذه الدراسة والتي تستخدم بيانات الأستر والجيوكيمياء في استكثاف نواجدات جديدة من الذهب في صخور الجرانوديوريت المتغيرة في نطاق سموت في جنوب الصحراء الشرقية مصر • وتكامل بيانات الأستر مع الدراسات الحقلية أنتج خريطة تبين نطاقات التغير في صخور الجرانوديوريت . نتنجة اختلافات المكونات المعدنية في المحاليل الحارمائية وشدة هذه المحاليل وتأثيرها على الصخور المحيطة تكونت عمليات تغيير متعددة في صخور الجرانوديوريت ـ من هذه العمليات العمليات السيريسيتية والكلورينية والسيليسية والفيروجينية وتكونت من تفاعل المحاليل المعدنية مع الصخور المحيطة ـ. وكل عملية تغير تحتوي معادن تغير مميزة لها فالعمليات السيليسية تتميز بعروق وحبيبات الكوارتز المهشمة أما وجود أكاسيد الحديد فيميز العمليات الفيروجينية .

التحاليل الكيمبائية لصذور الجرانوديوريت التي لم تتغير أظهرت محتوى ذهب يتراوح بين ppm and 1.61 ppm. 0.02 to 14.79 ppm أما صخور الجرانوديوريت المتغيرة فقد أظهرت محتوى ذهب يتزاوح بين إن وجود الذهب في صخور الجرانوديوريت التي لم تتغير و المتغيرة بكميات متفاوته وإن كانت فلبلة إلا أن مع انتشار وتواجد هذه الصخور بكميات كبيرة بعطي أهمية لاستكثاف الذهب واستغلاله في هذه المنطقة. 